\title{
Konsep Kebahagiaan AL-Kindi
}

\section{Isfaroh}

UIN Sunan Kalijaga Yogyakarta

isfaroh.37@gmail.com

\begin{abstract}
Happiness is a dream for every human being, but there are still many people who do not succeed in achieving happiness, this is because they do not understand the meaning and how to achieve happiness. This paper will discuss how to achieve happiness by thinking rationally in al-Kindi's thoughts. This research uses the verstehen method. For al-Kindi, rational thinking is virtue, which means imitating the deeds of God. So, happiness can be achieved by knowing the virtues and behaving in accordance with the demands of these virtues.
\end{abstract}

Keyword: happines, rationality, al-Kindi

Abstrak: $\quad$ Kebahagiaan merupakan impian bagi setiap manusia, akan tetapi masih banyak manusia yang tidak berhasil mencapai kebahagiaan, hal ini disebabkan karena belum memahami arti dan cara mencapai kebahagiaan. Tulisan ini akan membahas bagaimana mencapai kebahagiaan dalam bimbingan rasionalitas menurut pemikiran al-Kindi. Kajian ini menggunakan metode verstehen. Hasil kajian menunjukkan bahwa bagi al-Kindi, berfikir rasional adalah keutamaan, yang berarti meneladani perbuatan-perbuatan Tuhan. sehingga kebahagiaan dapat dicapai dengan cara mengetahui keutamaan dan bertingkah laku sesuai dengan tuntutan keutamaan tersebut.

Keywords: Kebahagiaan, Rasionalitas, al-Kindi 


\section{A. Pendahuluan}

Manusia adalah makhluk ciptaan Allah yang paling sempurna. Karena manusia dibekali dengan akal atau rasio, hal inilah yang membuatnya berbeda dengan makhluk yang lain. Dengan daya akal fikiran tersebut, setiap manusia hendak mencapai kehidupan yang bahagia, baik kebahagiaan didunia yang fana ini maupun kehidupan yang kekal diakherat nanti. Kebahagiaan adalah cita-cita bagi setiap manusia, akan tetapi masih banyak manusia yang tidak mengerti arti kebahagiaan yang hakiki. Sehingga meskipun sudah berusaha untuk mencapai kebahagiaan, maka tetap saja kehidupannya diwarnai dengan kesedihan dan kegelisahan.

Kenyataan ini telah membuat banyak pemikir yang terpanggil untuk menawarkan gagasan-gagasanya guna mengatasi persoalan tersebut, salah satunya al-Kindi.

Al-Kindi atau alkindus, ${ }^{1}$ nama lengkapnya Abu Yusuf Ya'kub ibn Ishaq ibn Shabbah ibn Imran ibn Ismail al-Ash'ats ibn Qais al$\mathrm{Kindi}^{2}$ Ia populer dengan sebutan al-Kindi, yaitu dinisbatkan kepada Kindah, yakni suatu kabilah yang terkemukan pra-Islam yang merupakan dari Bani Kahlan yang menetap di Yaman. ${ }^{3}$ Ia lahir di Kufah, tahun $801 \mathrm{M}$ dan wafat sekitar tahun $866 \mathrm{M} .{ }^{4}$ Ia lahir pada masa khalifah harun al-Rasyid (786-809 M) dari Dinasti Bani Abbas (750$1258 \mathrm{M})$. Al-Kindi lahir dari keluarga bangsawan, terpelajar, dan kaya. $^{5}$

Pemikiran al-Kindi tentu sudah banyak yang meneliti, antara lain Madani dengan judul "Pemikiran Filsafat al-Kindi", di dalam tulisan ini mengupas pemikiran al-Kindi tentang metafisika, karena sebagai seorang filosof Muslim pemikirannya tidak terlepas dari kajian

\footnotetext{
${ }^{1}$ Abubakar Madani, Pemikiran Filsafat al-Kindi, Jurnal: Lentera, Vol. IXX, No. 2, Desember 2015, h. 106.

${ }^{2}$ Charles E. Butterwort, The Political Aspects of Islamic Philosophy, (Harvard: Harvard University Press, 1992), h. 11. 15.

${ }^{3}$ Hasyimsyah Nasution, Filsafat Islam, (Jakarta: Gaya Media Pratama, 1999), h.

${ }^{4}$ Charles E. Butterwort, The Political Aspects of Islamic Philosophy, h. 12.

${ }^{5}$ Ayah al-Kindi, Ishaq ibn Shabbah, menjabat sebagai gubernur, pada masa Khalifah al-Mahdsi (775-785 M), al-Hadi (785-876 M), dan Harun al-Rasyid (786-909 M), masa kekuasaan Bani Abbas (750-1258 M). Ayahnya meninggal saat al-Kindi masih kecil.
} 
tauhid, yakni melihat konsep pemikiran tentang Tuhan, tulisan ini menjelaskan secara panjang lebar tentang pemikiran tersebut.

Selanjutnya pemikiran a-Kindi juga terdapat didalam beberapa buku diantaranya karya: Khabib Basori ${ }^{6}$, Saiful Hadi ${ }^{7}$, Muhyiddin Mas Rida. ${ }^{8}$ Beberapa karya tersebut menyajikan pemikiran al-Kindi mencakup aspek rasionalitas dan keilmiahan dalam pencapaian kebahagiaan, dan fungsi etika sebagai pengobatan ruhani. al-Kindi juga menjelaskan secara rasional-ilmiah alasan mengapa manusia dalam mencapai kebahagiaan harus melakukan tindakantindakan tertentu dan menghindarkan dari perilaku yang lainnya.

Pada artikel ini, penulis memilih untuk mengkaji bagaimana mencapai kebahagiaan dengan menggungakan rasionalitas menurut pemikiran al-Kindi? Adapun metode yang dipakai yaitu metode verstehen.

\section{B. Konsep Kebahagiaan}

Kebahagiaan dapat difahami sebagai keadaan atau perasaan senang, tenteram, dan terbebas dari semua yang sifatnya menyusahkan. jika mengacu pada definisi diatas, maka dapat fahami bahwa ketentraman menjadi unsur yang sangat penting dalam kebahagiaan. ${ }^{9}$

Kebahagiaan tidaklah sama dengan kenikmatan, kepuasan, dan kesenangan. Baik itu kenikmatan, kesenangan maupun kepuasan mungkin saja bisa mendatangkan kebahagiaan, akan tetapi ketiganya juga mungkin mendatangkan kesengsaraan. Lebih dari sekedar kesenangan, kepuasan, dan kenikmatan, maka kebahagiaan mendiskripsikan keadaan kejiwaan yang diliputi oleh rasa ketenteraman, yakni perpaduan dari rasa aman, damai, dan tenang. Apabila mengikuti definisi kebahagiaan seperti disebutkan di atas, maka kebahagiaan adalah sama seperti hilangnya sesuatu yang

\footnotetext{
${ }^{6}$ Khabib Basori, Ilmuwan-Ilmuwan Muslim Pengubah Zaman, (Klaten: Penerbit Cempaka Putih, 2009).

${ }^{7}$ Saiful Hadi. "Ilmuwan Muslim Pengukir Sejarah", (Jakarta: Insan Cemerlang dan Intimedia Cipta Nusantara, 2013).

${ }^{8}$ Muhyiddin Mas Rida, "Ilmuwan Terkemuka Dalam Sejarah Islam", Jakarta: Pustaka Al-Kautsar. Cet. Kedua (Terjemahan dari Kitab Abaqirah Ulama' Al-Hadharah wa Al-Islamiyah Karya Muhammad Gharib Gaudah, Maktabah Alquran, 2012).

${ }^{9}$ Majid Fakhry. Sejarah Filsafat Islam, terj. R. Mulyadhi Kartanegara (Jakarta: Pustaka Jaya, 1986), 361.
} 
menyusahkan. Banyak kemungkinan yang dapat menyebabkan kesusahan, contohnya bisa berupa hal-hal yang bersifat material, sosial, dan spiritual. Apabila merujuk pada ketiga hal yang dapat menyebabkan kesusahan itu, maka kebahagiaan juga terkait dengan ketiga hal tersebut. Ada kebahagiaan yang terkait dengan hal-hal yang bersifat material, hal-hal yang berifat (perilaku) sosial, dan ada hal-hal yang bersifat spiritual. Dengan demikian, cara yang dapat ditempuh oleh manusia untuk dapat mencapai kebahagiaan juga terkait dengan ketiga hal di atas, yaitu dengan memperoleh materi, memberi materi kepada orang lain, berperilaku yang menyengkan orang lain, dan mendapatkan pemahaman tentang sesuatu persoalan melalui pengerahan daya pikir. ${ }^{10}$ Pada umumnya ilmu pengetahuan bertolak pada pengklasifikasi kedalam dua kelompok. Pertama, pengetahuan teoritis, atau disebut dengan al-hikmah al-nazhariyyah. Kedua, pengetahuan praktis atau al-hikmah al-'amaliyyah, atau biasa disebut dengan al-'ilm al-madanî. Bagian pertama terkait dengan segala sesuatu sebagaimana adanya, sedangkan pada bagian kedua terkait dengan segala sesuatu sebagaimana seharusnya. ${ }^{11}$

Jika pengetahuan teoritis terkait dengan fisika, metafisika, dan psikologi, maka pengetahuan praktis terkait dengan etika, ekonomi, dan politik. Etika mengatur tentang bagaimana seharusnya individu berperilaku, ekonomi mengatur pengelolaan keuangan, sedangkan politik mengatur suatu Negara (al-madînah), politea. Dengan demikian, ilmu pengetahuan praktis mesti didasarkan atas pengetahuan teoritis. Dengan makna lain, di mana pengetahuan teoritis berakhir, disitulah pengetahuan praktis bermula. ${ }^{12}$

\section{Rasionalitas Sebagai Jalan Kebahagiaan}

Sebagai seorang filosof, Menurut al-Kindi berfikir rasional atau penggunaan daya fikir yang hakiki adalah upaya meneladani perbuatan-perbuatan Tuhan sejauh yang dapat dijangkau oleh kemampuan manusia. Dengan meneladani perbuatan-perbuatan Tuhan

${ }^{10}$ Mustain, Etika dan Ajaran Moral Filsafat Islam: Pemikiran Para Filosof Muslim tentang Kebahagiaan, Ulumuna Jurnal Studi Keislaman, Volume 17 Nomor 1 (Juni) 2013, h. 195.

${ }^{11}$ Yamani, Antara al-Fârâbî dan Khomeini: Filsafat Politik Islam, (Bandung: Mizan, 2002), h. 31-32.

12 Ibid, h. 32. 
tersebut diharapkan agar manusia memiliki keutamaan yang sempurna. Berfikir rasional juga latihan untuk mengendalikan diri, yaitu dengan jalan mengendalikan hawa nafsu sebagai jalan untuk memperoleh keutamaan. Sehingga sampai kepada pemahaman jika hanya kenikmatan dan kebahagiaan hidup lahiriah saja itu adalah keburukan. Dengan demikian bekerja untuk memperoleh kenikmatan lahiriah berarti tidak rasional dan meninggalkan fungsi akal. ${ }^{13}$

Terkait dengan berfikir yang rasional, Al-Kindi mengajukan pertanyaan: bagaimana cara untuk menjadi manusia yang memiliki keutamaan sempurna itu? Bagaimana cara untuk mengendalikan hawa nafsu agar dapat mencapai keutamaan itu. Selanjutnya al-Kindi menjawab pertanyaan yang diajukannya sendiri itu dengan menyatakan bahwa: ketahuilah keutamaan itu dan bertingkah lakulah sesuai dengan tuntutan keutamaan itu. ${ }^{14}$

Al-Kindi berpendapat bahwa keutamaan manusiawi tidak lain adalah budi pekerti manusiawi yang terpuji dan lawannya adalah kenistaan. Keutamaan-keutamaan ini kemudian dibagi menjadi tiga bagian. Pertama, merupakan asas dalam jiwa, yaitu pengetahuan dan perbuatan ilmu dan amal. Bagian ini juga dibagi menjadi tiga: pertama, kebijaksanaan (hikmah), kedua, keberanian (sajaah), ${ }^{15}$ ketiga, kesucian ('iffah). ${ }^{16}$ Kebijaksanaan adalah keutamaan daya berfikir yang dapat berupa kebijaksanaan teoritis dan kebijaksanaan praktis. Kebijaksanaan teoritis ialah mengetahui segala sesuatu yang bersifat universal secara hakiki, dan kebijaksanaan praktis ialah menggunakan kenyataan-kenyataan yang wajib dipergunakan. Keberanian merupakan sifat yang tertanam dalam jiwa yang memandang ringan pada kematian untuk mencapai dan menolak sesuatu yang harus ditolak. Adapun kesucian adalah memperoleh sesuatu yang memang harus diperoleh guna mendidik dan memelihara badan serta menahan diri dari yang tidak diperlukan untuk itu. ${ }^{17}$

Keutamaan kejiwaan tiga macam itu merupakan benteng keutamaan pada umumnya yang menjadi batas pemisah antara keutamaan dan kenistaan. Dengan kata lain, tiga macam keutamaan itu

\footnotetext{
${ }^{13}$ Maftukhin, Filsafat Islam, (Yogyakarta: Teras, 2012), h. 93.

${ }^{14}$ Ibid, h. 94.

${ }^{15}$ Charles E. Butterwort, The Political Aspects of Islamic Philosophy, h. 57.

${ }^{16}$ Musthofa, Filsafat Islam, (Bandung: Pustaka Setia, 2007), h. 110.

${ }^{17}$ Ibid, h. 111.
} 
merupakan induk dari keutamaan-keutamaan lainnya. Dengan demikian, keutamaan itu ialah tengah-tengah antara ujung ekstrim, melampaui batas semestinya, dan kenistaan adalah salah satu dari dua ujung tersebut. Kedua, keutamaan-keutamaan manusia tidak terdapat dalam jiwa, tetapi merupakan hasil dan buah dari tiga macam keutamaan tersebut, sehingga keutamaan yang Ketiga adalah hasil keadaan lurus dari tiga macam keutamaan itu yang tercermin dalam sikap keadilan. ${ }^{18}$ Dari uraian tersebut dapat dikatakan bahwa keutamaan-keutamaan manusia terdapat dalam sifat-sifat kejiwaan dan dalam buah yang dihasilkan oleh sifat-sifat itu. ${ }^{19}$ Jika orang hidup memenuhi nilai-nilai keutamaan, niscaya hasilnya akan hidup bahagia, selagi manusia dalam hidupnya berusaha memperoleh kebahagiaan itu menjadi tujuan akhir hidup, maka orang yang ingin menikmati kebahagiaan harusah berbekal keutamaan-keutamaan itu.

\section{Jiwa dan Akal sebagai Jalan Kebahagiaan}

Didalam khasanah pemikiran al-Kindi, pembahasan mengenai jiwa adalah yang pertama sekali yang ia lakukan. Al-Kindi mengungkapkan bahwa jiwa adalah jauhar al-basith, bersifat Ilahi, dan ruhani, (tunggal, tidak tersusun, tidak panjang, tidak lebar, tidak dalam) ia adalah nur yang bersumber dari nur Tuhan. Jiwa memiliki makna yang sangat penting, sempurna dan mulia. Substansi jiwa adalah berasal dari substansi Allah. Hubungan jiwa terhadapa Allah dapat digambarkan seperti hubungan cahaya dengan matahari. Menurut alKindi Jiwa memiliki wujudnya tersendiri, ia terpisah dan berbeda dari jasad, bersifat rohani dan Ilahi.

Menurut al-Kindi Jiwa adalah wujud yang sederhana, esensinya terpancar dari Tuhan yang dapat diilustrasikan identik dengan seperti terpancarnya cahaya dari matahari. Jiwa, menururt alKindi bersifat ketuhanan, spritual, terpisah dan berbeda dari jasad. Perbedaan antara jiwa dan jasad menurut al-Kindi karena sifat jiwa yang sering menentang keinginan hawa nafsu. Apabila nafsu marah mendorong manusia untuk melakukan kejahatan maka jiwa menentangnya. Dengan demikian, menurut pemahaman al-Kindi antara yang melarang "jiwa" dan yang dilarang "nafsu/amarah" pasti

\footnotetext{
${ }^{18}$ Charles E. Butterwort, The Political Aspects of Islamic Philosophy, h. 57.

${ }^{19}$ Musthofa, Filsafat Islam, h. 111.
} 
berbeda. Hanya saja Al-Kindi tidak menjelaskan terkait dengan keterangan waktu kapan jiwa diciptakan, apakah jiwa itu sudah ada sebelum badan ada atau lahir bersamaan dengan jasad.

Untuk mengilustrasikan perbedaan lain dari jiwa dan badan dapat ditunjukkan dengan hubungan mesin dan komponen sebuah mobil. Jika diamati waktu mesin mobil dalam kondisi hidup, bukan berarti secara otomatis semua komponennya difungsikan. Karena setiap komponen mesin akan difungsikan sesuai dengan kondisi yang dihadapinya. Ketika mobil berjalan di siang hari maka komponen yang difungsikan adalah gigi (porsneling), stir, kopling, sementara komponen lain tidak difungsikan. Lampu sen misalnya tidak difungsikan kecuali ketika akan berbelok. Lampu utama akan difungsikan ketika berjalan pada waktu malam, begitu juga dengan komponen lainnya. Dengan demikian, menurut al-Kindi, manusia tidak akan mampu menjelaskan sampai pada hakikat mengenai jiwa. Oleh sebab itu ia lebih menekankan pada realisasi jiwa.

Al-Kindi berpendapat bahwa jiwa itu tidaklah tersusun, akan tetapi jiwa memiliki arti yang sangat penting, sempurna, dan mulia. Mengapa demikian, karena menurut al-Kindi, Substansi jiwa itu berasal dari substansi Tuhan dan hubungannya dengan manusia sama seperti antara hubungan cahaya dengan matahari. Jiwa berbeda dengan jasad, bahkan mempunyai sifat yang bertentangan antara keduanya. Jiwa menurut al-Kindi secara hakikat bersifat spiritual dan Ilahi. Segala potensi buruk seperti nafsu birahi bisa jadi membuat manusia untuk berbuat keji, tetapi jiwa akan mengekangnya. Ketika jiwa berpisah dengan jasad, maka jiwa akan bersatu kembali dengan dunia realitas tempat cahaya Pencipta terbit. ${ }^{20}$

Pemikiran Al-Kindi mengenai jiwa banyak dipengaruhi oleh para filosof Yunani seperti Plato, Aristoteles, dan Plotinus, meskipun tidak seluruhnya al-Kindi sependapat dengan pemikiran mereka. Menurut Al-Kindi jiwa dapat didefinisikan sebagai suatu kesempurnaan awal bagi fisik yang bersifat alamiah, mekanistik, dan memiliki kehidupan yang energik, atau dengan istilah yang lain jiwa yaitu kesempatan fisik alami yang mempunyai alat dan mengalami kehidupan. Selain itu juga, Al-Kindi juga menyebutkan defenisi yang ditengarai bersumber dari Plato dan Plotinus, yang berpendapat bahwa

${ }^{20}$ Zaprulkhan, Filsafat Islam: Sebuah kajian Tematik, (Jakarta: Raja Grafindo Persada, 2014), h. 27. 
jiwa adalah sebagai elemen yang mempunyai kehormatan, kesempurnaan, berkedudukan luhur, dan substansinya berasal dari substansi Sang Pencipta. Defenisi yang terakhir ini Al-Kindi mengarahkan pengertiannya kepada jiwa rasional, atau dalam istilah al-Kindi al-Nafs al-Nathiqah.

Pendapat al-Kindi yang lainnya juga memiliki kesamaan dengan pendapat Plato, bahwa kesatuan jiwa dan badan atau jasad adalah kesatuan acciden (kebetulan), binasanya jasad tidak membawa binasanya jiwa. Tetapi disisi lain al-Kindi tidak menerima pendapat Plato yang meyakini jika jiwa berasal dari alam idea. Menurut pemahaman Plato "ide adalah kecerdasan berpikir". Dan disisi lain ide adalah unsur-unsur struktural dari sesuatu hal. Pada kontek ini ide merupakan gambaran dari sesuatu ketika berada dalam pikiran. Dapat difahami bahwa ide tidak sama dengan jiwa, karena jiwa bukan suatu bayangan dari materi, tetapi unsur lain materi. Pemahaman inilah yang menyebabkan ia tidak setuju dengan Plato terkait keyakinan jika asal jiwa dari ide.

Al-Kindi juga tidak sependapat dengan Aristoteles yang berpendapat bahwa jiwa merupakan bentuk dari jasadnya. Dengan pemahaman bahah materi ialah jasad dan bentuk ialah jiwa manusia. Jika demikian pemahamannya maka akan berimplikasi pada nalar bahwa jika hubungan jiwa dan jasad sama dengan hubungan bentuk dan materi, jiwa tidak dapat mempunyai wujud tanpa materi, dan materi juga tidak akan berwujud tanpa jiwa. Pendapat ini membawa implikasi bahwa jiwa adalah baru karena jiwa adalah form bagi badan. Jadi, Form tidak dapat berwujud tanpa materi, sehingga jiwa dan badan membentuk satu kesatuan yang esensial dan kemusnahan badan membawa kemusnahan jiwa.

Al-Kindi mempunyai pemahaman bahwa jiwa adalah substansi yang bersifat ilahi, rabbani dan berasal dari Cahaya Pencipta. Selain itu juga ia menambahkan bahwasannya jiwa adalah substansi sederhana yang tidak fana, substansi yang turun dari dunia akal ke dunia indera dan dianugerahi kekuatan memori akan masa lalunya. ${ }^{21}$ Al-Kindi berpendapat, bahwa sifatnya jiwa itu adalah kekal itu artinya jiwa tidak ikut hancur ketika badan atau jasad manusia hancur. Pemahamannya ini ia sandarkan pada rumusan awal pemikirannya

${ }^{21}$ Hasan Basri, Filsafat Islam, h. 41-42. 
mengenai jiwa, bahwa jiwa tidak mengalami hancur seperti jasad karena substansi dari jiwa itu berasal langsung dari Tuhan. Menurutnya, ketika jiwa itu mendiami jasad, maka jiwa itu tidak mendapatkan kebahagiaan yang sesungguhnya dan juga bentuk pengetahuannya tidak sempurna. Baru setelah jiwa terpisah dari jasad, jiwa akan mendapatkan perasaan senang yang sesungguhnya dalam bentuk pengetahuan yang sempurna. Hal ini dikarenakan ketika jiwa terpisah dari jasad, maka jiwa berpindah ke Alam Kebenaran atau Alam Akal (al-'alam a-haq, al-'alam al-aql). Di alam akal ini digambarkan oleh A-Kindi jiwa berada dalam lingkungan cahaya Tuhan, berada dekat pada Tuhan, serta bisa menatap Tuhan. Oleh karena itu menurutnya tempat ini adalah tempat dimana jiwa mendapatkan kebahagiaan yang hakiki, dan inilah tempat berdiamnya jiwa yang suci. Sementara bagi jiwa yang belum suci, setelah ai terpisah dengan jasad, maka jiwa tersebut tidak akan langsung berada pada alam ini, melainkan jiwa tersebut akan mengembara dalam jangka waktu tertentu dalam rangka mensucikan diri. ${ }^{22}$

Pada pemaparan diatas dapat difahami bahwa jiwa yang dipertemukan dengan jasad menciptakan komponen yang sudah dipersiapkan menjadi berfungsi. Dengan daya yang dimiliki jiwa, maka dialah yang menggerakan setiap komponen itu. Sebagiamana yang dikutip Harun Nasution menjelasan bahwa, menurut al-Kindi pada jiwa manusia terdapat tiga daya : daya nafsu (al-quwwat al-syahwaniyyat) yang terdapat dalam perut, daya marah (al-quwwat alghadhabiyyat) yang terdapat di dada, dan daya pikir (al-quwwat al-'aqliyyat) yang berpusat di kepala. ${ }^{23}$ Perut adalah komponen yang menjadi pusat keinginan-keinginan. Di sini jiwa menjalankan daya nafsu untuk mendapatkan kesenangan-kesenangan lahiriah. Ini terwujud dalam bentuk upaya pemenuhan setiap keinginan yang muncul dan dada merupakan komponen sebagai tempat bagi kemarahan. Adapun yang difahami sebagai dada yaitu perangkat yang terletak didalam dada yaitu qalb, ia adalah tempat bertumpuknya kasih sayang, marah, benci, perasaan senang, perasaan sedih dan sebagainya. Qalb adalah komponen dalam yang ditutupi dada, sedangkan dada yaitu bagian luarnya. Pada bagian qalb inilah jiwa mengaktifkan fungsi-fungsi tersebut, sehingga akan tampak apa yang terdapat didalam hati akan

${ }^{22}$ Abubakar Madani, Pemikiran Filsafat al-Kindi, h. 23.

${ }^{23}$ Charles E. Butterwort, The Political Aspects of Islamic Philosophy, h. 56. 
menjelma dalam tingkah laku. Sedangkan kepala yaitu komponen tubuh manusia yang berfungsi sebagai pusat berpikir, kepala disini yaitu otak. Pada ranah ini jiwa mengaktifkan daya pikir dalam rangka mempertimbangkan segala sesuatu secara jernih sehingga dapat menentukan pilihan mana yang baik dan mana yang buruk untuk dilakukan ruh atau jiwa tidak pernah tidur. Ketika badan tidur jiwa hanya tidak menggunakan atau menghentikan penggunaan indra. Setiap indra akan difungsikan sesuai dengan kebutuhan. Bila disucikan jiwa dapat melihat hal-hal yang luar biasa dalam mimpi, dapat berbicara dengan jiwa-jiwa yang lain yang telah terpisah dengan tubuhtubuh jasad. Selanjutnya daya berpikir itu disebut akal, dan akal terdiri dari tiga tingkat; (a) Akal yang masih bersifat potensial (al-quwwah), (b) Akal yang telah keluar dari potensial menjadi aktual ( $A l-F i$ ' $l$ ), dan (c) Akal yang telah mencapai tingkat kedua dari aktualitas (al-' $q l$ altsany), akal kedua. ${ }^{24}$

Sedangkan akal yang bersifat potensial tidak akan menjadi aktual jika tidak ada kekuatan yang menggerakkannya dari luar, yang mempunyai wujud tersendiri diluar jiwa manusia. Akal tersebut adalah akal yang selamanya aktualis (al-'aql al-ladzi bi al-fi'l abadan), dan ini memiliki ciri-ciri sebagai berikut: (a) merupakan Akal Pertama, (b) selamanya dalam aktualitas, (c) merupakan species dan genus, (d) membuat akal potensial menjadi aktual berpikir, dan (e) tidak sama dengan akal potensial tetapi lain dari padanya. ${ }^{25}$.

Kebahagiaan yang diperoleh dari proses-proses berpikir menempati tempat yang lebih tinggi dibandingkan dengan kebahagiaan yang dicapai melalui perbuatan kesusilaan. Bahkan menurut mereka kebahagiaan yang dicapai dari polah pikir yang mendalam dan hal-hal yang bersifat universal merupakan kebahagiaan tertinggi dan hanya bisa dicapai oleh orang-orang tertentu dan khusus. Akal manusia memiliki peran sangat penting dalam proses mencapai kebahagiaan. Akal dipandang sebagai unsur yang mengokohkan keyakinan untuk perilaku baik. Tugas itu diwujudkan dengan meneguhkan dalil-dalil rasional untuk memberi landasan mengapa manusia itu mesti berperilaku baik dan menghindari perilaku buruk dalam kehidupannya.

${ }^{24}$ Hana al-Fahuri dan Khalil al-Jarr, Tarikh al-Falsafah al-Arabiyyah. (Beirut: Muassas li al-Thaba'ah wa al-Nasyr, 1963), h. 366-367.

${ }^{25}$ Hasyimsyah Nasution, Filsafat Islam, h. 23. 
Oleh karena itu, al-Kindi membahas tentang moral mengaitkan dengan rasionalitas.

Kebahagiaan yang menjadi tujuan dalam pemikiran al-Kindi dicapai melalui proses yang melibatkan ilmu dan rasionalitas. Artinya bahwa kebahagiaan yang dicapai akan semakin tinggi tingkatannya apabila didukung dengan dalil-dalil intelektual. Dengan rasionalitasnya, manusia dapat membedakan mana tindakan yang baik dan tindakan yang tidak baik sehingga ia memiliki pengetahuan sebagai panduan dalam bertindak. Pengetahuan (ilmu) dan tindakan (amal) merupakan dua hal yang saling berhubungan. Pengetahuan (ilmu) memperoleh maknanya dalam wujud tindakan (perilaku), sebaliknya tindakan yang tidak didasari pengetahuan (ilmu) maka tidak mengandung nilai. Oleh karena itu, bahwa persoalan akal dalam pemikiran Al-Kindi dibicarakan bersamaan dengan pembicaraan jiwa. Akal sebagai agen pengetahuan yang mengontrol proses pembentukan pengetahuan melalui bantuan pengalaman inderawi, bagi Al-Kindi merupakan potensi yang ada dalam jiwa dan berkemungkinan untuk bergerak dari potensialitas menuju aktualitas. Akhirnya, semua pemikiran yang digagas Al-Kindi merupakan gagasan yang ditujukan untuk memperdalam pengetahuan manusia tentang dirinya. ${ }^{26}$ Idealnya, manusia paripurna tidak berada dalam wilayah teoritis, tapi dalam wilayah praktis. ${ }^{27}$

\section{E. Mendeteksi Penyakit Jiwa dan Cara Mengobatinya}

Al-Kindi dalam karyanya yang berjudul al-Hilâh li Daf' alAhzân (seni menepis kesedihan), al-Kindi berupaya menganalisis beberapa penyakit jiwa, diantaranya adalah kesedihan (al-huzn). Menurutnya kesedihan adalah penyakit jiwa yang disebabkan karena hilangnya apa yang dicinta dan luputnya apa yang didamba. Untuk mengobati kesedihan, al-Kindi menawarkan pengobatan sebagai berikut. Pertama, kesedihan karena hilangnya apa yang dicinta. Untuk mengobatinya, al-Kindi menganjurkan agar manusia memahami sifat dasar keberadaan makhluk di dunia yang fana ini. Dengan pemahaman yang sempurna sehingga melahirkan keyakinan bahwa apapun yang dicintai didunia ini pasti akan terpisah dan musnah. Oleh karena itu

${ }^{26}$ Charles E. Butterwort, The Political Aspects of Islamic Philosophy, h. 58.

${ }^{27}$ Abubakar Madani, Pemikiran Filsafat al-Kindi, h. 23. 
manusia janganlah mengharapkan sesuatu apapun yang ada pada diri ini menjadi kekal abadi, karena hal itu sama dengan mengharap yang tak mungkin dan akan menimbulkan kesedihan. Kedua, yaitu luputnya yang didamba bisa diatasi dengan mengembangkan sikap hidup yang sederhana, suka menerima (qanâ 'ah), menyesuaikan keinginan dengan kemampuan dan kemungkinan yang dimiliki, agar tidak lebih besar pengeluaran daripada penghasilan. ${ }^{28}$

Al-Kindi menyatakan bahwa didunia ini tidak ada yang bersifat abadi, tidak ada sesuatu yang menjadi hak milik pribadi, yang ada hanya kepemilikan sementara. Manusia sering merasa memiliki dan menginginkan apa yang dimilikinya bersifat abadi, sehingga ketika apa yang dimiliki itu dan yang diinginkan hilang, manusia pasti mengalami kesedihan, jiwa manusia mengalami problem keguncangan.

Berikut ini al-Kindi memberikan nasehat kepada orang-orang yang hidupnya diliputi rasa penderitaan dan kesusahan. Menurut alKindi, jika diperhatikan apa sebab timbulnya kesusahan pada kebanyakan orang, akan dijumpai bahwa sebabnya ada dua. Pertama, karena orang kehilangan sesuatu yang dimilikinya. kedua, karena ia tidak berhasil memperoleh sesuatu yang ia inginkan yang sifatnya kebendaan. Jika orang hidup menyandarkan kebahagaiaannya kepada memiliki, menguasai dan memperoleh kekayaan kebendaan, maka orang itu telah menyimpang dari jalan yang benar. Kebahagiaan sebenarnya terletak pada jiwa, tidak ada yang dimiliki oleh jiwa. Semua yang bersifat kebendaan wataknya dapat mengalami perubahan dan hilang. Orang yang berakal seharusnya tidak menyandarkan kebahagiaan hidupnya dengan yang berubah dan hilang itu. Mungkin yang dirasakan paling indah di antara benda-benda yang mengalami perubahan dan hilang itu adalah permata dan mutiara, padahal itu semua tidak lebih hanyalah batu-batuan tanah dan kerang-kerang air. Jika barang-barang itu didudukkan pada kedudukan yang hakiki, orang akan berpendapat bahwa barang-barang seperti itu tidak patut menyebabkan kesusahan jika hilang. ${ }^{29}$

Al-Kindi menceritakan tentang Socrates, ketika Socrates ditanya mengapa ia tidak pernah kelihatan susah. Jawabnya: saya tidak

${ }^{28}$ Mustain, Etika dan Ajaran Moral Filsafat Islam: Pemikiran Para Filosof Muslim Tentang Kebahagiaan, Ulumuna Jurnal Studi Keislaman, Volume 17 Nomor 1 (Juni) 2013, h. 201.

${ }^{29} \mathrm{Ibid}, \mathrm{h} .112$. 
memiliki sesuatu yang patut saya susahkan jika hilang. Ditanya mengapa ia tidak pernah kelihatan sengsara, padahal tidak pernah berbagai macam kenikmatan material dalam hidupnya. Jawabnya: saya tidak pernah merasa tidak memperoleh sesuatu yang memang tidak saya ingini. ${ }^{30}$

Meletakkan materi pada proporsinya yang hakiki jika seseorang memiliki sesuatu yang tidak sangat menginginkan untuk memiliki sesuatu yang belum diperolehnya yang dapat menimbulkan rasa sengsara dan susah. Atas dasar bahwa hidup manusia di dunia ini hanya untuk sementara waktu, maka orang berakal jangan menambatkan kebahagiaannya kepada barang-barang yang bersifat material yang ahirnya pasti akan ditinggalkan juga.

Al-Kindi menegaskan, jika kita mendambakan kebahagiaan yang hakiki, maka wajiblah kita memiliki permata-permata dan mutiara-mutiara alam baka itu. Kita wajib memiliki kekayaan akaliah yang tidak akan mengalami kemusnahan, tidak binasa dan tidak dapat dirampas orang lain. di dalam pengetahuan terdapat kegembiraan dan kenikmatan. Itulah hidup yang kekal. Katakanlah kepada orang yang suka menangis, yang pembawaannya cengeng terhadap hal-hal yang menyusahkan, seharusnya ia menangisi orang yang mengabaikan kewajiban terhadap dirinya. Orang yang berakal dalam menghadapi barang-barang material diibaratkan oleh al-Kindi sebagai raja yang mencapai puncak kebesarannya. ${ }^{31}$

Menurut al-Kindi, memperdalam pengetahuan manusia tentang diri dan bahwa seorang filsuf wajib menempuh hidup susila. Hikmah sejati membawa serta pengetahauan serta pelaksanaan keutamaan. Kebijaksanaan tidak dicari untuk diri sendiri, ${ }^{32}$ melainkan untuk hidup bahagia. ${ }^{33}$ Kebahagiaaan yang ditemukan seseorang dalam mengenal Tuhan. maka tujuan dari moral adalah pengetahuan untuk memperoleh kebijaksanaan dan menghindari kejahatan. Pengetahuan tidak hanya diperlukan untuk membedakan antara baik dan jahat, tetapi untuk membantu menjaga kemurnian jiwa yang merupakan satu-

\footnotetext{
${ }^{30}$ Ibid, h. 112.

31 Ibid, h. 113.

32 Ungkapan Aristoteles.

${ }^{33}$ Hal ini seperti yang dikatakan oleh Stoa.
} 
satunya cara untuk mendekatkan diri kepada Tuhan, agar mendapat kebahagiaan sejati. ${ }^{34}$

Kebahagiaan sangat terkait dengan kesusilaan. Al-Kindi memandang kesusilaan sebagai prasyarat untuk tercapainya kebahagiaan, atau dapat dinyatakan dalam ungkapan "jadilah orang baik, maka engkau akan menjadi orang yang bahagia". Keterkaitan antara kebahagiaan dan ajaran moral dapat dijelaskan melalui hubungan antara kebaikan dan kebahagiaan. Moral bukan hanya membicarakan tentang tindakan yang baik yang dilakukan manusia, tetapi sekaligus "mengharuskan" manusia untuk selalu berbuat kebaikan dengan keutamaan-keutamaan. Hal itu dikarenakan kebaikan yang dilakukan manusia pada akhirnya pasti akan menghasilkan kebahagiaan. Manusia harus menjadi baik, karena hanya dengan menjadi baiklah seseorang akan menjadi bahagia. ${ }^{35}$

Orang baik adalah orang yang sehat mentalnya, dan orang yang sehat mentalnya akan dapat merasakan kebahagiaan-kebahagiaan ruhani. Sebaliknya apabila jiwa tidak sehat, misalnya karena ada penyakit dengki, maka manusia tidak akan dapat merasakan kebahagiaan. Bahkan ia akan merasa tidak berbahagia manakala ada orang lain yang merasakan kebahagiaan. Dengan demikian, perilaku yang baik atau terpuji (akhlâk al-karîmah) akan menjamin seseorang mencapai kebahagiaan dalam kehidupan. ${ }^{36}$

Tabiat manusia baik, tetapi digoda oleh nafsu. Hal ini dihapuskan oleh pengetahuan. Manusia harus menjauhkan diri dari keserakahan. Memiliki itu memberatkan jiwa. Sokrates dipuji sebagai contoh zahid (asket). Al-Kindi mengecam para ulama yang memperdagangkan agama untuk memperkaya diri, selain itu para filsuf juga mengecam yang memperlihatkan jiwa kebinatangan untuk mempertahankan jiwa kebinatangannya untuk mempertahankan kedudukannya dalam negara. ${ }^{37}$ Ia merasa kisah Socrates merupakan kezaliman dan ketidakadilan yang dilakukan oleh orang-orang yang

${ }^{34}$ George N. Atiyeh, al-Kindi: The Philosopher of The Arabs, (India: Kitab Bhavan, 1994), h. 111.

${ }^{35}$ Mustain, Etika dan Ajaran Moral Filsafat Islam: Pemikiran Para Filosof Muslim Tentang Kebahagiaan, h. 196.

${ }^{36}$ Ibid., h. 197.

${ }^{37}$ Charles E. Butterwort, The Political Aspects of Islamic Philosophy, h.54. 
memiliki otoritas negara. ${ }^{38}$ Di dalam kesesakan jiwa, filsafat menghiburnya dan mengarahkan untuk melatih kekangan, keberanian dan hikmah dalam keseimbangan sebagai keutamaan pribadi, begitupula ditekankan untuk berlaku adil dalam tatanan negara. AlKindi prihatin jika syari'at tidak menjamin perkembangan kepribadian seseorang, dalam artian fungsi syariat tidak digunakan baik. Oleh karena itu, dalam pemikiran moral, al-Kindi condong terhadap pemikiran Socrates dan Stoa. ${ }^{39}$

Kebajikan moral yang diturunkan dari keutamaan-keutamaan melahirkan sikap keadilan. Di dalam ranah filsafat Politik al-Kindi memberikan konstribusi dengan memadukan pemikiran Islam yang bersumber dari al-Qur'an dengan pemikiran para filosof Yunani untuk mengatasi kesejahteraan terhadap pengembangan individu dan tata kelola peningkatan kelompok atau hidup bersosial di masyarakat. Menurut al-Kindi untuk membahas tentang kebajikan manusia harus merujuk kepada wahyu (al-Qur'an) dan pemikiran filosof Yunani, karena keduanya saling melengkapi ${ }^{40}$

\section{F. Penutup}

Menurut al-Kindi, untuk mencapai kebahagiaan dapat ditempuh dengan jalan berfikir rasional, befikir rasional adalah suatu usaha dalam rangka meneladani perbuatan-perbuatan Tuhan. Dengan panduan akal yang syarat dengan ilmu pengetahuan, manusia akan mampu menetapkan kemana ia akan menyandarkan kebahagiaannya. Sehingga akan terhindar dari menyandarkan kebahagiaan pada sesuatu yang bersifat material dan kebendaan semata. Jika seseorang menyandarkan kebahagaiaannya kepada pemilikan, penguasaan dan mendapatkan kekayaan yang bersifat kebendaan, maka seseorang tersebut telah menyimpang dari jalan yang benar. Karena kebahagiaan sebenarnya terletak pada jiwa, dan tidak ada yang dimiliki oleh jiwa. Semua yang bersifat kebendaan wataknya dapat mengalami perubahan dan hilang. seseorang yang mendayagunakan akal fikirannya tidak akan menyandarkan kebahagiaan hidup kepada sesuatu yang sifatnya berubah dan hilang. [.]

\footnotetext{
${ }^{38}$ Hasyimsyah Nasution, Filsafat Islam, h. 24.

${ }^{39} \mathrm{Ibid}, \mathrm{h} .24$.

${ }^{40}$ Charles E. Butterwort, The Political Aspects of Islamic Philosophy, h. 59.
} 
Isfaroh

\section{Daftar Rujukan}

Basri, Hasan. Filsafat Islam. Jakarta: Direktorat Jenderal Pendidikan Islam, Kementerian Agama Republik Indonesia, 2013.

E. Butterwort, Charles. The Political Aspects of Islamic Philosophy. Harvard: Harvard University Press, 1992.

Fakhry, Majid. Sejarah Filsafat Islam: Sebuah Peta Kronologis. terj, Zaimul Am. Bandung: Mizan, 2001.

Al-Fahuri, Hana dan Khalil al-Jarr, Tarikh al-Falsafah al-Arabiyyah. Beirut: Muassas li al-Thaba'ah wa al-Nasyr, 1963.

Haryatmoko. Etika Politik dan Kekuasaan. Jakarta: Kompas, 2003.

Khudori Soleh, A. Filsafat Islam: Dari Klasik Hingga Kontemporer. Jogjakarta: Ar-Ruzz Media, 2013.

Madani, Abubakar. Pemikiran Filsafat al-Kindi. Jurnal: Lentera, Vol. IXX, No. 2, Desember 2015.

Maftukhin, Filsafat Islam. Yogyakarta: Teras, 2012.

Musthofa, Filsafat Islam. Bandung: Pustaka Setia, 2007.

Nasution, Hasyimsyah. Filsafat Islam, (Jakarta: Gaya Media Pratama, 1999), h. 15.

N. Atiyeh, George. al-Kindi: The Philosopher of The Arabs. India: Kitab Bhavan, 1994.

Rusydi, Ibnu. Filsafat Politik Islam. Jurnal Risaalah, Vol. 1, No. 1, Desember 2015.

Yamani, Antara al-Fârâbî dan Khomeini: Filsafat Politik Islam. Bandung: Mizan, 2002. 